\title{
The importance of central auditory evaluation in Friedreich's ataxia
}

\author{
A importância da avaliação auditiva central na ataxia de Friedreich \\ Bianca Simone Zeigelboim', Hélio A. G. Teive², Michèlli Rodrigues da Rosa', Jéssica Spricigo Malisky', \\ Vinicius Ribas Fonsecaํ, Jair Mendes Marques', Paulo Breno Liberalesso ${ }^{3}$
}

\begin{abstract}
Objective: To assess central auditory function in Friedreich's ataxia. Methods: A cross-sectional, retrospective study was carried out. Thirty patients underwent the anamnesis, otorhinolaryngology examination, pure tone audiometry, acoustic immittance measures and brainstem auditory evoked potential (BAEP) assessments. Results: The observed alterations were: $43.3 \%$ in the pure tone audiometry, bilateral in 36.7\%; 56.6\% in the BAEP test, bilateral in 50\%; and 46.6\% in the acoustic immittance test. There was a significant difference ( $p<0.05$ ) in the comparison between the tests performed. Conclusion: In the audiological screening, there was a prevalence of the descending audiometric configuration at the frequency of $4 \mathrm{kHz}$, and absence of the acoustic reflex at the same frequency. In the BAEP test, there was a prevalence of an increase of the latencies in waves I, III and V, and in the intervals of interpeaks I-III, I-V and III-V. In $13.3 \%$ of the patients, wave $V$ was absent, and all waves were absent in $3.3 \%$ of patients.
\end{abstract}

Keywords: spinocerebellar degenerations; hearing disorders; Friedreich ataxia; evoked potentials, auditory; ataxic gait.

\section{RESUMO}

Objetivo: Avaliar a função auditiva central na ataxia de Friedreich (AFRD). Métodos: Foi realizado um estudo retrospectivo de corte transversal. 30 pacientes realizaram anamnese, avaliações otorrinolaringológica, audiológica, imitanciométrica e do potencial evocado auditivo de tronco encefálico (PEATE). Resultados: As alterações observadas foram: 43,3\% no exame audiométrico sendo 36,7\% dos casos, bilateralmente; $56,6 \%$ na avaliação do PEATE com 50\% dos casos, bilateralmente e 46,6\% no exame imitanciométrico. Houve diferença significativa $(p<0,05)$ na comparação entre os exames realizados. Conclusão: No exame audiológico, ocorreu uma preponderância maior da configuração audiométrica descendente a partir da freqüência de $4 \mathrm{kHz}$ e ausência do reflexo acústico na mesma frequência. No exame do PEATE, houve prevalência do aumento das latências nas ondas I, III e V, e nos intervalos dos interpicos I-III, I-V e III-V. Em 13,3\% dos casos, a onda $V$ estava ausente, e em 3,3\% dos casos, todas as ondas estavam ausentes.

Palavras-chave: degenerações espinocerebelares; transtornos da audição; ataxia de Friedreich; potenciais evocados auditivos; marcha atáxica.

Hereditary ataxias take up about $10 \%$ of genetic diseases affecting the nervous system. Their classification is made according to their etiopathogenesis. Among them, Friedreich's ataxia, which was initially described by Nicholas Friedreich, stands out. It is a progressive neurodegenerative disease with recessive autosomal inheritance and early onset in most cases $^{1,2,3}$.

The mutation responsible for this disease is found in chromosome 9, where the GAA triplet repeat expansion in the FXN gene occurs ${ }^{4}$. The affected gene encodes the mitochondrial protein, frataxin, involved in iron metabolism ${ }^{2,3,4}$. The deficit of that protein causes iron accumulation within the mitochondria, thus impairing the respiratory chain ${ }^{2,3,4,5}$.

The first symptoms are usually observed in childhood or early adolescence. However, in some cases, it can be diagnosed before two or after 20 years of age. The main characteristics of this disease are: ataxia (impaired coordination), initially in the lower limbs and subsequently in the upper limbs; absence of tendon reflexes and weakness of lower limbs; dysarthria; loss of deep distal sensitivity; and bilateral Babinski signs. Studies on neural conduction have shown sensitive axonal neuropathy ${ }^{4,5,6}$. Other features may be associated with the main symptoms, such as: nystagmus, optical

1Univesidade Tuiuti do Paraná ,Departament of Otoneurology, Curitiba - Paraná State, Brazil;

${ }^{2}$ Universidade Federal do Paraná, Hospital de Clínicas, Neurology Service, Curitiba - Paraná State, Brazil;

${ }^{3}$ Hospital Pequeno Príncipe, Departament of Neurology, Curitiba - Paraná State, Brasil.

Correspondence: Bianca Simone Zeigelboim; Departamento de Otoneurologia da Universidade Tuiuti do Paraná, Rua Sydnei Antonio Rangel Santos, 238; 82010-330 Curitiba PR, Brasil; E-mail: biancacwb@yahoo.com.br

Conflict of interest: There is no conflict of interest to declare.

Received 19 September 2017; Received in final form: 26 November 2017; Accepted: 14 December 2017. 
atrophy, hearing loss (may be present), hand atrophy and distal atrophy in the lower limbs, scoliosis, pes cavus and claw-toe deformity ${ }^{2,3,4,5,6}$. Diabetes may be present in $10 \%$ of the patients, and cardiomyopathy may occur in about two-thirds of the patients, whichis the main cause of mortality ${ }^{6,7}$. There are significant differences in the lifespan of affected individuals, which tends to be around four decades from the disease onset until death ${ }^{4,5,8}$.

Screening of the peripheral and central auditory system is carried out by means of behavioral, acoustic-electric and electrophysiological assessment methods.

The brain is responsible for speech processing, beginning in the cochlea, where mechanical activity turns into nerve impulses. From the neurophysiological point of view, hearing entails a complex system, comprising a peripheral and a central part (cortical and subcortical structures). Whenever there is a physical dysfunction, a deficit in speech recognition skills occurs. Sound perception is performed by the central activity, and sound sensation is generated by the peripheral activities. While the peripheral auditory system receives and analyzes environmental auditory stimuli, the brain analyzes inner representations of acoustic stimuli9.

The effects caused by degenerative processes may involve the central auditory system, and disorders occur due to changes that directly affect brain mechanisms that process auditory information ${ }^{10}$.

In the past decades, a growing number of research studies, involving auditory function in neurodegenerative diseases, has been reported. Biacabe et al. ${ }^{11}$ state that the most evidenced auditory dysfunctions in neurodegenerative diseases have been observed in the brainstem auditory evoked potential (BAEP) testing, and usually occur in the inferior colliculus, lateral lemniscus and cochlear nuclei.

The current study assessed the auditory function in patients suffering from Friedreich's ataxia.

\section{METHODS}

This study was approved by the Institutional Ethics Board, Brazil Platform, opinion n ${ }^{\circ}$. 832.502/2014, and was authorized by patients after signing the Free Informed Consent Form.

A cross-sectional, retrospective study was carried out. Thirty (30) patients (10 females and 20 males), diagnosed with Friedreich's ataxia, were referred by the Department of Internal Medicine of the Hospital de Clinicas for assessment in the Department of Otoneurology of a teaching institution in the samecity. An ataxia diagnosis was reached by means of genetic testing using the polymerase chain reaction technique ${ }^{12,13}$. In order to measure the severity of the cerebellar ataxia in an easier and more practical way, Schmitz-Hübsch et al..$^{14}$ propose a scale for the assessment and rating of ataxia - SARA- translated and validated in Brazilian Portuguese by Braga-Neto et al. ${ }^{15}$. SARA has eight items that yield a total score of 0 (no ataxia) to 40 (most severe ataxia); 1: gait (score 0 to 8), 2: stance (score 0 to 6), 3: sitting (score 0 to 4), 4: speech disturbance (score 0 to 6), 5 : finger chase (score 0 to 4), 6: nose-finger test (score 0 to 4), 7 : fast alternating hand movements (score 0 to 4 ), 8: heel-shin slide (score 0 to 4 ). Limb-kinetic functions (items 5 to 8 ) are rated independently for both sides, and the arithmetic mean of both sides is included in the SARA total score ${ }^{15}$. This scale has proven to be valid and reliable in patients with ataxia.

The patients' ages ranged from six to 72 years, with a mean age of 38.7 years, and standard deviation of 17.7 years. Disease duration was between three and 42 years, with a mean duration of 14.7 years and standard deviation of 9.4 years (Table 1 ).

Table 1. Summary of patient demographics.

\begin{tabular}{|c|c|c|c|}
\hline$P$ & Age(y) and Sex & Disease duration (y) & SARA \\
\hline 1 & $43 / \mathrm{M}$ & 25 & 20 \\
\hline 2 & $41 / M$ & 7 & 3.5 \\
\hline 3 & $30 / F$ & 18 & 8 \\
\hline 4 & $24 / M$ & 8 & 4 \\
\hline 5 & $29 / M$ & 13 & 14 \\
\hline 6 & $17 / M$ & 3 & 13 \\
\hline 7 & $63 / F$ & 38 & 7 \\
\hline 8 & $6 / F$ & 5 & 19 \\
\hline 9 & $37 / F$ & 19 & 16 \\
\hline 10 & $41 / F$ & 20 & 29.5 \\
\hline 11 & $27 / F$ & 12 & 14 \\
\hline 12 & $25 / F$ & 12 & 12 \\
\hline 13 & $55 / F$ & 30 & 7 \\
\hline 14 & $44 / M$ & 10 & 3.5 \\
\hline 15 & $55 / M$ & 12 & 14 \\
\hline 16 & $37 / M$ & 17 & 19 \\
\hline 17 & $51 / M$ & 30 & 29 \\
\hline 18 & $27 / M$ & 10 & 16 \\
\hline 19 & $46 / \mathrm{M}$ & 18 & 10 \\
\hline 20 & $72 / \mathrm{M}$ & 42 & 28 \\
\hline 21 & $52 / F$ & 18 & 3 \\
\hline 22 & $30 / \mathrm{M}$ & 4 & 4.5 \\
\hline 23 & $37 / M$ & 19 & 18 \\
\hline 24 & $44 / M$ & 18 & 9.5 \\
\hline 25 & $22 / M$ & 14 & 5 \\
\hline 26 & $42 / F$ & 31 & 25 \\
\hline 27 & $63 / \mathrm{M}$ & 18 & 19 \\
\hline 28 & $42 / M$ & 21 & 8 \\
\hline 29 & $28 / M$ & 21 & 8 \\
\hline 30 & $30 / \mathrm{M}$ & 17 & 13 \\
\hline
\end{tabular}

M: male; F: female; SARA: scale for the assessment andrating of ataxia. 
Patients excluded from the research had otologic disorders or other abnormalities that prevented them from undergoing the examinations. Seven (7) patients were excluded from the study (three of them died and four refused to participate in the research). Audiological assessments were carried out in a single session, which lasted an average of 50 minutes.

The patients were submitted to the following procedures: Anamnesis: Patients answered a questionnaire with emphasis on otoneurological signs and symptoms.

Otorhinolaryngology examination: Performed with the objective of excluding any other disorders that could interfere with the examination.

Pure tone audiometry: Patients were submitted to pure tone air conduction threshold audiometry at frequencies from $250 \mathrm{~Hz}$ to $8 \mathrm{kHz}$; pure tone bone conduction threshold audiometry at frequencies from $500 \mathrm{~Hz}$ to $4 \mathrm{kHz}$, speech recognition threshold and speech discrimination tests. For those tests, the Madsen Itera audiometer - GN Optometrics, with TDH-39 headphones from GN-ReSound, was used and hearing level (HL) thresholds were measured indB. The equipment was calibrated according to ISO 8253. The levels and types of hearing loss were analyzed according to Davis et Silverman ${ }^{16}$.

Brainstem auditory evoked potential: This test used two channels with a click stimulus at 90dBHL, alternate polarity with a presentation frequency of 21.1 cycles per second, window of $15 \mathrm{~ms}, 30 \mathrm{~Hz}$ to $3 \mathrm{kHz}$ filter and at least 2,000 stimuli, and two rounds of repetition. Kendall Med trace 2000 electrodes were placed on the right and left mastoids, as well as on the Fz position (10-20 system), and ground electrodes on the forehead. Clicks were presented via 3A insert earphones. Wave latencies I, III and V and interpeak intervals I-III, III-V, I-V were analyzed according to Hall's criteria ${ }^{17}$. These waves represent structures of the auditory pathway, having the following generator sites: wave I - distal portion of the cochlear nerve; wave II - proximal portion of the cochlear nerve; wave III - generated in the cochlear nucleus; wave IV - superior olivary complex; wave V - lateral lemniscus; wave VI - inferior colliculus; and wave VII: medial geniculate body. In this study, latency values of waves I, III and V were used, as well as their interpeak latencies I-III, III-V and I-V. The choice ofthose three waves was because they feature greater amplitude and stability. In patients with hearing loss, it was necessary to increase the intensity of the click stimulus to 100 dBHL. The equipment used was Bio-logic's Evoked Potential System.

Acoustic immittance evaluation: This procedure was done to assess the integrity of the middle ear according to Jerger's criteria $^{18}$. The immittance equipment used was the Madsen OTOflex tympanometer, with TDH 39P earphones by GN-ReSound.

\section{Statistical analysis}

Pearson's correlation coefficient was used to correlate age, disease duration and the SARA scale; the two-proportion z-test was used to determinedifferences in proportion for symptoms analysis; and Fisher's exact test was carried out to compare the results of the audiological examinations, the BAEP and the measure of acoustic immittance (analyzing normal and abnormal results). Statistica 13.1 software was used, and the null hypothesis was rejected at 0.05 or $5 \%$.

\section{RESULTS}

By correlating age, disease durationand the result of the SARA scale, Pearson's correlation coefficient was significant in the correlation between disease duration and age ( $\left.p={ }^{*} 0.0000\right)$, and in the correlation betweendisease duration and the SARA scale $\left(\mathrm{p}={ }^{*} 0.0022\right)$ (Table 2$)$.

The most reported complaints in the anamnesis were: uncoordinated movement (66.7\%), gait imbalance $(56.7 \%)$, and dizziness (50\%). Hearing loss occurred in $10 \%$ of the patients (Table 3).

Table 2. Correlation between age, disease duration and SARA.

\begin{tabular}{lcc}
\hline Correlation & $\begin{array}{c}\text { Pearson's coefficient } \\
\text { correlation }(r)\end{array}$ & $p$ \\
\hline $\begin{array}{l}\text { Age and disease } \\
\text { duration }\end{array}$ & 0.7171 & $\star 0.0000$ \\
$\begin{array}{l}\text { Age and SARA } \\
\begin{array}{l}\text { Disease duration } \\
\text { and SARA }\end{array}\end{array}$ & 0.1911 & 0.0312 \\
\hline
\end{tabular}

SARA: scale for the assessment and rating of ataxia. * Significant comparison; $p$-values for Pearson's coefficient correlation shown.

Table 3.Symptoms in 30 patients withFriedreich's ataxia.

\begin{tabular}{lcc|}
\hline Symptoms & N. patients & Frequency (\%) \\
\hline Incoordination of movement & 20 & 66.7 \\
\hline Gaitimbalance & 17 & 56.7 \\
\hline Dizziness & 15 & 50.0 \\
\hline Dysarthria & 14 & 46.7 \\
\hline Headache & 10 & 33.4 \\
\hline Dysphagia & 9 & 30.0 \\
\hline Diplopia & 9 & 30.0 \\
Falling & 8 & 26.7 \\
Tremor & 8 & 26.7 \\
\hline Depression & 8 & 26.7 \\
Fatigue & 7 & 23.4 \\
Anxiety & 7 & 23.4 \\
Pain, difficulty in neck movement & 6 & 20.0 \\
\hline Tingling in extremities & 4 & 13.4 \\
Insomnia & 3 & 10.0 \\
\hline Hearingloss & 3 & 10.0 \\
\hline Olfactory alteration & 2 & 6.7 \\
Gustatory alteration & 2 & 6.7 \\
Dysphonia & 1 & 3.4 \\
\hline
\end{tabular}


In the two-proportion z-test, in orderto determinedifference in proportions, there were significant differences for the symptoms of uncoordinated movement $\left(\mathrm{p}<{ }^{*} 0.0010\right)$, gait imbalance $\left(\mathrm{p}<{ }^{*} 0.0370\right)$ and dizziness $\left(\mathrm{p}<{ }^{*} 0.0330\right)$ in relation to the other reported symptoms.

In the audiological assessment, 13/30 patients (43.3\%) hadhearing alterations:3.3\% in the right ear only, $3.3 \%$ in the left ear only, and $36.7 \%$ bilaterally (Table 4 ).

Results for the speech recognition threshold and speech recognition percentage index were comparable with the pure tone thresholds.
In the BAEP assessment, 17/30 patients (56.6\%) featured alterations: $3.3 \%$ in the right ear only, $3.3 \%$ in the left ear only, and $50 \%$ bilaterally, as shown in Table 4 .

In the acoustic immittance evaluation,14/30 patients (46.6\%) showed alterations in the acoustic reflex, all of which were bilateral (Table 5).

The results of the audiological assessments, BAEP and acoustic immittance evaluation, regarding the proportions for normal and alterations, are shown in Table 6.

Fisher'sexact test showed a significant difference between the audiological evaluation and BAEP $\left(\mathrm{p}={ }^{*} 0.0007\right)$, between

Table 4. Summary of each patient's audiological and BAEP results.

\begin{tabular}{|c|c|c|c|c|}
\hline \multirow{2}{*}{ Patient } & \multicolumn{2}{|c|}{ Audiology assessment } & \multicolumn{2}{|c|}{ BAEP } \\
\hline & RE & LE & $\mathrm{RE}$ & LE \\
\hline 1 & Normal & Normal & Abnormal & Abnormal \\
\hline 2 & Normal & Normal & Normal & Normal \\
\hline 3 & Normal & Normal & Abnormal & Abnormal \\
\hline 4 & Normal & Normal & Normal & Normal \\
\hline 5 & Sloping from $4 \mathrm{kHz}$ & Sloping from $4 \mathrm{kHz}$ & Abnormal & Abnormal \\
\hline 6 & Normal & Normal & Normal & Normal \\
\hline 7 & SNHL severe & SNHL severe & Abnormal & Abnormal \\
\hline 8 & Normal & Normal & Normal & Normal \\
\hline 9 & Normal & Normal & Abnormal & Abnormal \\
\hline 10 & SNHL mild & Normal & Abnormal & Normal \\
\hline 11 & Normal & Normal & Normal & Normal \\
\hline 12 & Normal & Normal & Normal & Normal \\
\hline 13 & Sloping from $3 \mathrm{kHz}$ & Sloping from $3 \mathrm{kHz}$ & Abnormal & Abnormal \\
\hline 14 & Normal & Normal & Normal & Normal \\
\hline 15 & Sloping from $2 \mathrm{kHz}$ & Sloping from $2 \mathrm{kHz}$ & Abnormal & Abnormal \\
\hline 16 & Normal & Normal & Abnormal & Abnormal \\
\hline 17 & Sloping from $2 \mathrm{kHz}$ & Sloping from $2 \mathrm{kHz}$ & Abnormal & Abnormal \\
\hline 18 & Normal & SNHL severe & Normal & Abnormal \\
\hline 19 & Normal & Normal & Abnormal & Abnormal \\
\hline 20 & Sloping from $2 \mathrm{kHz}$ & Sloping from $2 \mathrm{kHz}$ & Abnormal & Abnormal \\
\hline 21 & Sloping from $4 \mathrm{kHz}$ & Sloping from $4 \mathrm{kHz}$ & Abnormal & Abnormal \\
\hline 22 & Normal & Normal & Normal & Normal \\
\hline 23 & Sloping from $4 \mathrm{kHz}$ & Sloping from $4 \mathrm{kHz}$ & Normal & Normal \\
\hline 24 & Notchat $6 \mathrm{kHz}$ & Notchat $6 \mathrm{kHz}$ & Abnormal & Abnormal \\
\hline 25 & Normal & Normal & Normal & Normal \\
\hline 26 & Sloping from $4 \mathrm{kHz}$ & Sloping from $4 \mathrm{kHz}$ & Abnormal & Abnormal \\
\hline 27 & SNHL severe & SNHL moderate & Abnormal & Abnormal \\
\hline 28 & Normal & Normal & Normal & Normal \\
\hline 29 & Normal & Normal & Normal & Normal \\
\hline 30 & Normal & Normal & Normal & Normal \\
\hline
\end{tabular}

SNHL: sensorineural hearing loss; RE: right ear; LE: left ear; Statistical findings are reported in the Results; BAEP: brainstem auditory evoked potential. 
Table 5. Summary of each patient's acoustic immittance results.

\begin{tabular}{|c|c|c|c|c|}
\hline \multirow{3}{*}{ Patient } & \multicolumn{4}{|c|}{ Acoustic immittance } \\
\hline & \multicolumn{2}{|c|}{ Right ear } & \multicolumn{2}{|c|}{ Left ear } \\
\hline & Tympanometry curve & Acousticreflex & Tympanometry curve & Acousticreflex \\
\hline 1 & Type A & Absent at $3-4 \mathrm{kHz}$ & Type A & Absent at $3-4 \mathrm{kHz}$ \\
\hline 2 & Type A & Present & Type A & Present \\
\hline 3 & Type A & Absent at $4 \mathrm{kHz}$ & Type A & Absent at $4 \mathrm{kHz}$ \\
\hline 4 & Type A & Present & Type A & Present \\
\hline 5 & Type A & Absent at $4 \mathrm{kHz}$ & Type A & Absent at $4 \mathrm{kHz}$ \\
\hline 6 & Type A & Present & Type A & Present \\
\hline 7 & Type A & Absent & Type A & Absent \\
\hline 8 & Type A & Present & Type A & Present \\
\hline 9 & Type A & Absent at $4 \mathrm{kHz}$ & Type A & Absent at $4 \mathrm{kHz}$ \\
\hline 10 & Type A & Present & Type A & Present \\
\hline 11 & Type A & Present & Type A & Present \\
\hline 12 & Type A & Present & Type A & Present \\
\hline 13 & Type A & Absent at $3-4 \mathrm{kHz}$ & Type A & Absent at $3-4 \mathrm{kHz}$ \\
\hline 14 & Type A & Present & Type A & Present \\
\hline 15 & Type A & Absent at $3-4 \mathrm{kHz}$ & Type A & Absent at $3-4 \mathrm{kHz}$ \\
\hline 16 & Type A & Present & Type A & Present \\
\hline 17 & Type A & Absent at $2-4 \mathrm{kHz}$ & Type A & Absent at $2-4 \mathrm{kHz}$ \\
\hline 18 & Type A & Absent at $3-4 \mathrm{kHz}$ & Type As & Absent at $3-4 \mathrm{kHz}$ \\
\hline 19 & Type A & Present & Type A & Present \\
\hline 20 & Type A & Absent at $3-4 \mathrm{kHz}$ & Type A & Absent at $3-4 \mathrm{kHz}$ \\
\hline 21 & Type A & Absent at $4 \mathrm{kHz}$ & Type A & Absent at $4 \mathrm{kHz}$ \\
\hline 22 & Type A & Present & Type A & Present \\
\hline 23 & Type A & Absent at $4 \mathrm{kHz}$ & Type A & Absent at $4 \mathrm{kHz}$ \\
\hline 24 & Type A & Present & Type A & Present \\
\hline 25 & Type A & Present & Type A & Present \\
\hline 26 & Type A & Absent at $4 \mathrm{kHz}$ & Type A & Absent at $4 \mathrm{kHz}$ \\
\hline 27 & Type A & Absent & Type A & Absent \\
\hline 28 & Type A & Present & Type A & Present \\
\hline 29 & Type A & Present & Type A & Present \\
\hline 30 & Type A & Present & Type A & Present \\
\hline
\end{tabular}

Statistical findings are reported in the results text.

Table 6. Distributions of audiological, BAEP and acoustic immittance test results in Friedreich's ataxia.

\begin{tabular}{|c|c|c|c|c|}
\hline Variables & Normal (n) & Abnormal (n) & Total (n) & $P$ \\
\hline \multicolumn{5}{|c|}{ Audiology findings } \\
\hline \multicolumn{5}{|l|}{ BAEP } \\
\hline Normal & 12 & 5 & 17 & \multirow{3}{*}{$\star 0.0007$} \\
\hline Abnormal & 1 & 12 & 13 & \\
\hline Total & 13 & 17 & 30 & \\
\hline \multicolumn{5}{|c|}{ Acoustic immittance } \\
\hline Normal & 14 & 3 & 17 & \multirow{3}{*}{$\star 0.0000$} \\
\hline Abnormal & - & 13 & 13 & \\
\hline Total & 14 & 16 & 30 & \\
\hline \multicolumn{5}{|l|}{ BAEP findings, $N$} \\
\hline \multicolumn{5}{|c|}{ Acoustic immittance } \\
\hline Normal & 12 & 1 & 13 & \multirow{3}{*}{ *0.0002 } \\
\hline Abnormal & 4 & 13 & 17 & \\
\hline Total & 16 & 14 & 30 & \\
\hline
\end{tabular}

BAEP: brainstem auditory evoked potential; *Significant comparison; $p$ values for Fisher's exacttests shown. audiological evaluation and acoustic immittance evaluation $\left(\mathrm{p}={ }^{*} 0.0000\right)$, and between BAEP and acoustic immittance evaluation $\left(\mathrm{p}={ }^{*} 0.0002\right)$.

\section{DISCUSSION}

In the analysis of the disease duration and age variables, it was observed that the older the patient, the longer the disease duration, as most patients suffered from the disease since childhood/adolescence; and the longer the disease duration, the worse the score result on the SARA scale.

The anamnesis disclosed a prevalence of gait disorders, which were expected in spinocerebellar ataxias. Speech disorders, dizziness, dysphagia, dysphonia, and hearing loss are also described in several studies ${ }^{1,2,3}$. According to Payne $^{19}$, patients develop primary neurodegeneration in the 
dorsal root ganglia, which explains the loss of proprioception and coordination.

Abnormalities in the audiological evaluation were present in $43.3 \%$ of the ataxic patients. Knezevic and Stewart-Wynne $e^{20}$ assessed 18 patients with spinocerebellar ataxia and observed normal hearing in all of them; however, five of the seven (71\%) Friedreich's ataxia patients had abnormal BAEP results, where only wave I was identified, and $71 \%$ of the olivopontocerebellar atrophy patients had abnormal BAEP results. The results showed severe abnormalities in the brainstem auditory pathways in patients with spinocerebellar ataxia.

In the current study, $56.6 \%$ of the patients had alterations in the BAEP test, with the occurrence of latency increases in waves I, III and V, and in the interpeak intervals I-III, I-V and III-V for $12 / 17$ patients (40\%); wave V was absent in 4/17 (13.3\%) patients, and all waves were absent in one (3.3\%) patient.

Yokoyamaet al. ${ }^{21}$ assessed 30 patients with spinocerebellar degeneration and verified increases in latency and interpeak intervals of waves I-III and I-V; wave V was absent in $30 \%$ of the patients, and $82.5 \%$ showed altered wave ranges. Rance et al. ${ }^{22}$ assessed two patients with audiological follow-ups for a period of three years, BAEP and central auditory processing examinations being performed periodically. The global severity of the disease in the initial assessment was equivalent in both cases. The authors showed axonopathy in the cochlear nerve in both cases. They observed hearing loss (significant neural reduction) along the course of the disease. Zeng et al. ${ }^{23}$ showed that diseases that affect the integrity of the auditory nerve drastically impair hearing perception. In another study, Rance et al. ${ }^{24}$ observed interrupted neural activity in the BAEP in nine out of 14 patients with Friedreich's ataxia. The same authors reported that an impaired auditory pathway is a relatively common consequence in this disease. Satya-Murti et al. ${ }^{25}$ showed a normal audiological evaluation, and alteration in all waves of the BAEP in four patients diagnosed with Friedreich's ataxia. They reported that these alterations could be attributed to the degeneration of the spiral ganglion neurons. A study by López-Diaz-de León et al. ${ }^{26}$ assessed two adolescents with Friedreich's ataxia, who showed abnormalities in the BAEP with normal otoacoustic emissions, pointing to auditory neuropathy. Thus, auditory thresholds were normal in one patient, and the other was diagnosed with a mild sensorineural hearing loss. Pelosiet al. ${ }^{27}$ assessed 15 patients with Friedreich's ataxia and observed the presence of wave I, and absence of wave $\mathrm{V}$ in all patients, irrespective of the symptom durationor the clinical severity of the disease, raising the hypothesis that these alterations were related to primary axonal degeneration. Santarelli et al. ${ }^{28}$ stated that the sensory neural hearing loss is one of the clinical features of Friedreich's ataxia, and most patients present auditory neuropathy. According to the authors, the neuropathy was explained by the presence of faulty nerve connections due to the loss of inner hair cells, causing the interruption of the acoustic signal. Spinelli et al. ${ }^{29}$ reported that auditory neuropathy was a dysfunction of the auditory nerve, which caused a disconnection in the nerve conduction, probably related to an alteration in the myelination of those fibers, probably located in the inner hair cells and in their synapses. Auditory neuropathy has been observed in Friedreich's ataxia, Guillan-Barré and Charcot-Marie-Tooth type II diseases.

The measurement of the acoustic immittance was altered in $46.6 \%$ of the Friedreich's ataxia patients in our study, and there was no reference to this finding in the literature to compare with our results. It is known thatfibers leave the anterior cochlear nuclei and go, via the trapezoidal body, to the nuclei of the contralateral facial nerve, and on to the superior olivary complex, which in turn, make synapses with the nucleus of the facial nerve. The ipsilateral fibers from the anterior cochlear nuclei establish these connections and, from the nuclei of the facial nerves, axons innervate the stapes muscles. Thus, in neurodegenerative diseases, the anterior cochlear muscles are impaired, with possible interferences in the mechanism of the acoustic reflex ${ }^{30}$.

In the current study, there was a higher prevalence of alterations in the BAEP test, which showed significant alterations in the integrity of the brainstem auditory pathway. This finding corroborates the literature, where Yokoyama et al. ${ }^{21}$ reported alterations in several structures of the central auditory pathway, showing a higher sensitivity of the BAEP test in detecting alterations of the acoustic impulse along the central auditory pathway.

In conclusion, the most-reported change in the audiological assessment was the prevalence of the descending audiometric configuration at the frequency of $4 \mathrm{kHz}$, and bilateral absence of the acoustic reflex at the frequency of $4 \mathrm{kHz}$.

In the electrophysiological evaluation, $40 \%$ of the patients had alterations, mostly showing an increase of the latencies in waves I, III and V, and in the interval of interpeaks I-III, I-V and III-V. In $13.3 \%$ of the patients, wave V was absent and, in one patient (3.3\%), all waves were absent.

Therefore, it is importantto study the central auditory system using an electrophysiological assessment to detect abnormalities in the brainstem auditory pathway in this population.

\section{References}

1. Fogel BL, Perlman S. Clinical features and molecular genetics of autosomal recessive cerebellar ataxias. Lancet Neurol. 2007 Mar;6(3):245-57. https://doi.org/10.1016/S1474-4422(07)70054-6
2. Embiruçu EK, Martyn ML, Schlesinger D, Kok F. Autosomal recessive ataxias: 20 types, and counting. ArqNeuropsiquiatr. 2009 Dec;67(4):1143-56. https://doi.org/10.1590/S0004-282X2009000600036 
3. Ell J, Prasher D, Rudge P. Neuro-otological abnormalities in Friedreich's ataxia.J Neurol Neurosurg Psychiatry. 1984 Jan;47(1):26-32. https://doi.org/10.1136/jnnp.47.1.26

4. Albano LM, Zatz M, Kim CA, Bertola D, Sugayama SM, Marques-Dias $\mathrm{MJ}$ et al. Friedreich's ataxia: clinical and molecular study of 25 Brazilian cases. Rev Hosp Clin Fac Med Sao Paulo. 2001 Sep-Oct;56(5):143-8. https://doi.org/10.1590/S0041-87812001000500003

5. Alper G, Narayanan V. Friedreich's ataxia. Pediatr Neurol. 2003 May;28(5):335-41. https://doi.org/10.1016/S0887-8994(03)00004-3

6. Pandolfo M. Friedreich ataxia. Arch Neurol. 2008 Oct;65(10):1296-303. https://doi.org/10.1001/archneur.65.10.1296

7. Melo M, Fagulha A, Barros L, Guimarães J, Carrilho F, Carvalheiro M. [Friedreich ataxia and diabetes mellitus: family study]. Acta Med Port. 2005 Nov-Dec;18:479-83. Portuguese.

8. Baloh RW, Konrad HR, Honrubia V. Vestibulo-ocular function in patients with cerebellar atrophy. Neurology. 1975 Feb;25(2):160-8. https://doi.org/10.1212/WNL.25.2.160

9. Pereira LD, Schochat E. Processamento auditivo central: manual de avaliação. São Paulo: Lovise; 1997.

10. Aquino AMCM, organizer. Processamento auditivo: eletrofisiologia \& psicoacústica. São Paulo: Lovise; 2002.

11. Biacabe B, Chevallier JM, Avan P, Bonfils P. Functional anatomy of auditory brainstem nuclei: application to the anatomical basis of brainstem auditory evoked potentials. Auris Nasus Larynx. 2001 Jan;28(1):85-94. https://doi.org/10.1016/S0385-8146(00)00080-8

12. Dueñas AM, Goold R, Giunti P. Molecular pathogenesis of spinocerebellar ataxias. Brain. 2006 Jun;129(Pt 6):1357-70. https://doi.org/10.1093/brain/awl081

13. Pearson CE, Nichol Edamura K, Cleary JD. Repeat instability: mechanisms of dynamic mutations. Nat Rev Genet. 2005 Oct;6(10):729-42. https://doi.org/10.1038/nrg1689

14. Schmitz-Hübsch T, Montcel ST, Baliko L, Berciano J, Boesch S, Depondt $\mathrm{C}$ et al. Scale for the assessment and rating of ataxia: development of a new clinical scale. Neurology. 2006 Jun;66(11):1717-20. https://doi.org/10.1212/01.wnl.0000219042.60538.92

15. Braga-Neto P, Godeiro-Júnior C, Dutra LA, Pedroso JL, Barsottini OG. Translation and validation into Brazilian version of the scale of the assessment and rating of ataxia (SARA). ArqNeuropsiquiatr. 2010 Apr;68(2):228-30. https://doi.org/10.1590/S0004-282X2010000200014

16. Davis H, Silverman RS. Hearing and deafness. 3rd ed. New York: Holt, Rinehart \& Wilson; 1970.

17. Hall J. Handbook of auditory evoked responses. Boston: Allyn \& Bacon; 1992
18. Jerger J. Clinical experience with impedance audiometry. Arch Otolaryngol. 1970 Oct;92(4):311-24. https://doi.org/10.1001/archotol.1970.04310040005002

19. Payne RM. The heart in Friedereich's ataxia: basic findings and clinical implications. Prog Pediatr Cardiol. 2011 May;31(2):103-9. https://doi.org/10.1016/j.ppedcard.2011.02.007

20. Knezevic W, Stewart-Wynne EG. Brainstem auditory evoked responses in hereditary spinocerebellar ataxias. Clin Exp Neurol. 1985;21:149-55.

21. Yokoyama J, Aoyagi M, Suzuki T, Kiren T, Koike Y. Three frequency component wave forms of auditory evoked brainstem response in spinocerebellar degeneration. Acta Otolaryngol Suppl. 1994;511 sup511:52-5. https://doi.org/10.3109/00016489409128301

22. Rance G, Corben LA, Delatycki MB. Auditory pathway changes mirror overall disease progress in individuals with Friedreich ataxia.J Neurol. 2012 Dec;259(12):2746-8. https://doi.org/10.1007/s00415-012-6679-z

23. Zeng FG, Kong YY, Michalewski HJ, Starr A. Perceptual consequences of disrupted auditory nerve activity. J Neurophysiol. 2005 Jun;93(6):3050-63. https://doi.org/10.1152/jn.00985.2004

24. Rance G, Corben L, Barker E, Carew P, Chisari D, Rogers M et al. Auditory perception in individuals with Friedreich's ataxia. Audiol Neurootol. 2010;15(4):229-40. https://doi.org/10.1159/000255341

25. Satya-Murti S, Cacace A, Hanson P. Auditory dysfunction in Friedreich ataxia: result of spiral ganglion degeneration. Neurology. 1980 Oct;30(10):1047-53. https://doi.org/10.1212/WNL.30.10.1047

26. López-Díaz-de-León E, Silva-Rojas A, Ysunza A, Amavisca R, Rivera R. Auditoryneuropathy in Friedreich ataxia. A report of two cases. Int J Pediatr Otorhinolaryngol. 2003 Jun;67(6):641-8. https://doi.org/10.1016/S0165-5876(03)00036-3 27.

27. Pelosi L, Fels A, Petrillo A, Senatore R, Russo G, Lönegren $K$ et al. Friedreich's ataxia: clinical involvement and evoked potentials. Acta Neurol Scand. 1984 Nov;70(5):360-8. https://doi.org/10.1111/j.1600-0404.1984.tb00837.x

28. Santarelli R, Cama E, Pegoraro E, Scimemi P. Abnormal cochlear potentials in Friedreich's ataxia point to disordered synchrony of auditory nerve fiber activity. Neurodegener Dis. 2015;15(2):114-20. https://doi.org/10.1159/000375307

29. Spinelli M, Fávero-Brewel MI, Silva CM. [Auditory neuropathy: clinical, diagnostic and therapeutic aspects]. Ver Bras Otorrinolaringol. 2001;67(6):863-7. Portuguese. https://doi.org/10.1590/S0034-72992001000600017

30. Carvalho RM. Imitância acústica. Zeigelboim BS, Jurkiewicz AL, organizers. Multidisciplinaridade na otoneurologia. São Paulo: Roca; 2012. p. $122-3$ 